\title{
XRCC1 wt Allele
}

National Cancer Institute

\section{Source}

National Cancer Institute. XRCC1 wt Allele. NCI Thesaurus. Code C51012.

Human XRCC1 wild-type allele is located in the vicinity of 19q13.2 and is approximately 32 $\mathrm{kb}$ in length. This allele, which encodes DNA-repair protein XRCC1, is involved in the repair of single-strand DNA breaks and sister chromatid exchange. A rare microsatellite polymorphism in this allele is associated with cancer in patients of varying radiosensitivity in cancer patients. 